\title{
Lake water quality observed after extreme rainfall events: implications for water quality affected by stormy runoff
}

\author{
Takehiko Fukushima $^{1,2} \mathbb{D} \cdot$ Tatsumi Kitamura $^{1} \cdot$ Bunkei Matsushita $^{2}$
}

Received: 2 February 2021 / Accepted: 27 September 2021

Published online: 12 October 2021

(c) The Author(s) $2021 \quad$ OPEN

\begin{abstract}
To investigate the effects of extreme rainfall events (EREs) on lake water quality, we analyzed the lake monthly monitoring data at the stations close to inflow rivers. We tested the hypothesis that the effects depend on rainfall magnitude, season, distance from the rivers, etc. The highest correlations with many water-quality indicators were obtained for the rainfall amount for the preceding 10 days before the water sampling days; i.e., negatively with $\mathrm{Na}^{+}, \mathrm{Cl}^{-}$, chlorophyll a (Chla), and COD, and positively with ortho-phosphate. We used the threshold of rainfall amount $\geq 140 \mathrm{~mm}$ to choose EREs and evaluate the water quality on such occasions because quite low values of $\mathrm{Na}^{+}, \mathrm{Cl}^{-}$, and Chla thresholds ( $\leq 25$ th percentile) were observed in some of the EREs. The event samples (group $1 ; G 1$ ) meeting the above thresholds probably represented the inflow waters during EREs (generally occurred in Oct-May), and the others (group 2; G2) indicated significant changes in the lakes (Jun to Sep), probably depending on the lake's state of primary production. In the events of lower rainfall events ( $50 \mathrm{~mm}$ to $140 \mathrm{~mm}$ for 10 days), fast recoveries of algal production usually occurred even in Oct to May. The values of COD, total phosphorus, and ortho-phosphate in G1 were higher than the values of river water quality in the baseflow conditions, whereas both the $\mathrm{G} 1$ and baseflow values of nitrogen were nearly the same. The effects of ERFs on lake water quality from the viewpoints of tempo-longitudinal distributions, future monitoring, and climate change were discussed.
\end{abstract}

Keywords Extreme rainfall event $\cdot$ Baseflow $\cdot$ Water quality monitoring data $\cdot$ Climate change

\section{Introduction}

As global climate changes intensify, large rainfall events (LREs) and extreme rainfall events (extremely large rainfall events; EREs) will increase in magnitude [1-3]. Lehmann et al. [4] presented the first analysis of record-breaking daily rainfall events using observational data and showed that over the last three decades the number of recordbreaking events has significantly increased in the global mean (12\% more events over 1981-2010 compared with those expected in stationary time series).

Because stormwater runoff can significantly affect the export of nutrients [5-7] and thereby affect the phytoplankton [8,9] and aquatic vegetation [10] communities in downstream lakes, it is crucial to predict and evaluate the effects of stormwater runoff from the viewpoint of lake environment management. The large majority of watershed phosphorus $(\mathrm{P})$ export occurs during high-flow

Supplementary Information The online version contains supplementary material available at https://doi.org/10.1007/s42452-02104823-x.

Takehiko Fukushima, fukushima.takehik.fu@u.tsukuba.ac.jp | I'baraki Kasumigaura Environmental Science Center, 1854 Okijyuku, Tsuchiura, Ibaraki 3000023, Japan. ${ }^{2}$ Faculty of Life and Environmental Sciences, University of Tsukuba, 1-1-1 Tennoudai, Tsukuba, Ibaraki 3058572, Japan.

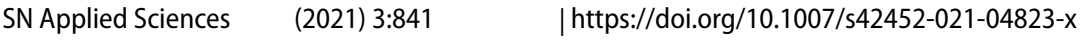


conditions, suggesting that without substantial management change, more frequent EREs arising from climate change will drive increased $P$ losses from agricultural watersheds [11] and bring about cyanobacterial blooms in downstream lakes [9]. In Lake Maggiore, a deep oligotrophic lake, EREs led to a short-term increase in nutrient that stimulated the growth of blooms of phytoplankton and the development of blooms in summer, when epilimnetic waters were usually nutrient depleted [12].

In contrast, increased discharge rates during the peak flushing season (Sep-Dec) were correlated to diminished cyanobacterial biomass despite elevated nutrient levels in a large shallow eutrophic lake, Lake George [13]. Richardson et al. [14] indicated that one of the potential effects of EREs on phytoplankton communities was greater loss of biomass through hydraulic flushing. Based on a shallow lake mesocosm experiment to test the combined effects of warming, high rainfall (flushing) event, and nutrient loading on total phytoplankton biomass and cyanobacterial abundance and composition, a recovery from flushing was slowest in the winter, but unaffected by warming or higher nutrient loading. Analyzing the effects of seven major cyclones from 1999 to 2017, an extremely large flood caused the water column to destabilize prematurely and depressed primary production in Lough Feeagh, a relatively large humic oligotrophic lake [15]. Asmala et al. [16] analyzed the effects of seven major tropical cyclones from 1999 to 2017 on the quantity and fate of dissolved organic carbon (DOC) in the Neuse River Estuary (NC, USA) and reported that the elevated dissolved organic carbon lasted for 20-200 days. The results suggested pulsed terrestrial DOC associated with tropical cyclones overwhelmed the estuarine filter's abiotic and biotic degradation capacity.

During rainfall events, particularly in large stormy events, indicators of water quality as well as water discharge change to a great extent, and the water discharge/ quality relationships usually show characteristics of hysteresis $[17,18]$. Thus, gaging and water sampling at a high frequency are thus necessary to accurately measure the total load. In addition, sufficient numbers of events with different rainfall amounts should be investigated in order to evaluate the effects of the events on the water quality and ecosystem in downstream lakes. Using the data of 72 events, Zhang et al. [19] analyzed the relationship between the mean concentrations of baseflow and the dischargeweighted event concentrations of 10 water constituents from forested watersheds. As evidenced by that study, challenging research in the field and laboratory is necessary to estimate the loads of LREs/EREs.

Lake Kasumigaura is a shallow eutrophic lake in Japan. Ebise [20] measured the nutrient loads at several points in the rivers inflowing to this lake during dozens of rainfall events, and he proposed their stormy runoff models based on the data. Detailed observations after such rainfall events have not been conducted in this lake with the exception of one of the estuaries [21]. In that study, the dynamics of $\mathrm{P}$, nitrogen $(\mathrm{N})$, and other water-quality indicators were described for the direct runoff period due to a rainfall of $23 \mathrm{~mm}$ (which is not very large for that region) along with a budgetary calculation in the estuarine area. The effects of stormy runoff on a lake's water quality have not been analyzed based on significant amounts of monitoring data at roughly regular intervals.

As indicated by previous studies, the effects of LREs/ EREs on lake water quality would be dependent on rainfall magnitude, season, distance from the inflowing rivers, etc. In order to test this hypothesis, we analyzed the monitoring data obtained near the mouths of inflow rivers because they were frequently and greatly affected by LREs/EREs. Thus, the purposes of the present study were to: (1) investigate the relationship between rainfall amounts and lake water quality at these stations considering the seasons when the events happened; (2) make rough estimates of the river water quality during EREs using the monitoring data because accurate estimate of runoff loads in inflowing rivers was quite tough; (3) compare these estimates with those observed in dry weather periods and/or eventaveraged estimates in inflow rivers obtained in a previous study; and (4) evaluate the effects of extreme stormy events from the whole lake scale.

\section{Methods}

\subsection{Lakes Kasumigaura and Kitaura}

As illustrated in Fig. 1, Lake Kasumigaura, the second largest lake in Japan $\left(172 \mathrm{~km}^{2}\right)$, is located in the eastern part of Japan's Kanto Plain [22]. It has a mean depth of $3.4 \mathrm{~m}$ and a maximum depth of $7.0 \mathrm{~m}$. Its water retention time is $\sim 200$ d. The land use in the lake's watershed is 20\% forest, $24 \%$ paddy fields, $14 \%$ plowed fields, and $43 \%$ residential and other uses. Approx. 874,000 people live in the watershed (2015). Agricultural (rice, vegetable, etc.) and stock raising industries (swine, beef/dairy cattle, poultry/hen raising) are active. Annual amount of industrial shipment exceeds two trillion JPY. More than 20 rivers flow into the lake; the four main rivers (i.e., the Sakura, Koise, Ono, and Shintone Rivers) are shown in Fig. 1. Water tends to flow through the lake from the northwest to the southeast and finally to the effluent Kitatone River.

Lake Kitaura $\left(36 \mathrm{~km}^{2}\right)$ is another shallow lake with a mean depth of $4.5 \mathrm{~m}$ and maximum depth of $7.1 \mathrm{~m}$ [16]. The main river (i.e., the Tomoe River) is shown in Fig. 1. This lake is connected to Lake Kasumigaura through the Wani River, Lake Sotonasakaura $\left(12 \mathrm{~km}^{2}\right)$, and the Kitatone River, 


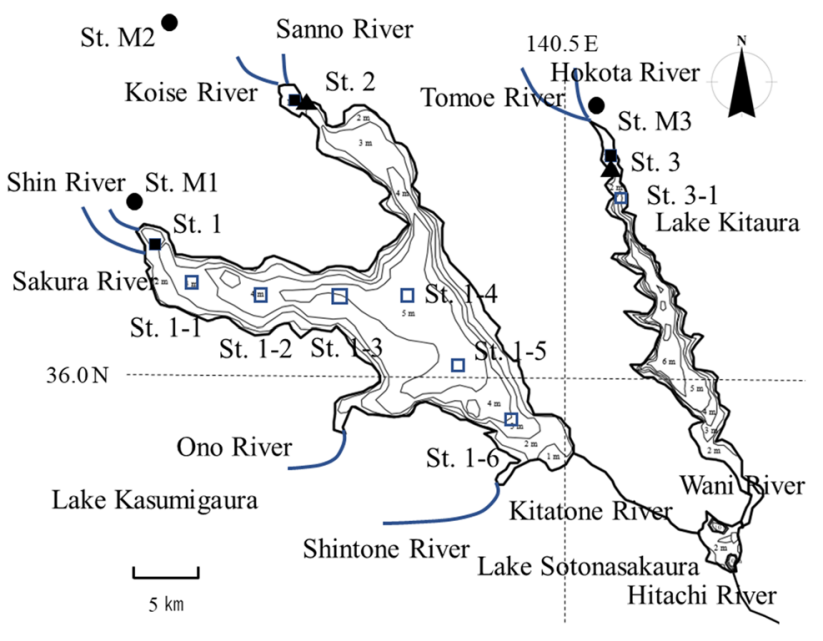

Fig. 1 Target water region (Lake Kasumigaura and Lake Kitaura) and monitoring points. Solid squares: Water sampling points close to influent river. Open squares: Water sampling points in offshore areas. Solid triangles: Stations for continuous water-quality monitoring. Solid circles: Stations for meteorological observation

all of which are located downstream of the two lakes. The water retention time of Lake Kitaura is $\sim 160 \mathrm{~d}$. The land use in the watershed of Lake Kitaura is 23\% forest, $14 \%$ paddy fields, $25 \%$ plowed fields, and $39 \%$ residential and other uses. Approx. 90,000 people live in the watershed (2015). Agricultural and stock raising industries are more active compared with the Lake Kasumigaura basin. Annual amount of industrial shipment exceeds 287 billion JPY. Diurnal stratification is sometimes formed under a weakwind condition in these lakes [23], but vertical stratification is easily destroyed by strong winds due to the lakes' shallow depths [24].

\subsection{Data}

We used the results of monthly monitoring (include the surveys conducted only a few times per month in limited years) at eight stations in Lake Kasumigaura and two stations in Lake Kitaura from Jun 2005 to Mar 2020 for the present analyses $(n=175)$. The main purposes of this monitoring are to retrieve the lake conditions related to eutrophication and to propose restoration plans to mitigate the deteriorated states. Water samples were taken $0.5 \mathrm{~m}$ below the water surface because nearly uniform vertical profiles of water quality indicators were usually observed [24]. The following 12 indicators for water quality were analyzed: sodium $\left(\mathrm{Na}^{+}\right)$, chloride $\left(\mathrm{Cl}^{-}\right)$, chlorophyll a (Chla), chemical oxygen demand (COD), dissolved COD (D-COD), total organic carbon (TOC), dissolved organic carbon (DOC), total nitrogen (TN), total phosphorus (TP), nitrate nitrogen $\left(\mathrm{NO}_{3}{ }^{-} \mathrm{-}\right)$, ortho-phosphate $\left(\mathrm{PO}_{4}{ }^{3-}-\mathrm{P}\right)$, and dissolved silicon (Si). These indicators were analyzed based on the Japanese Industrial Standards
(JIS) K 0102-2016 testing methods. In addition to the abovementioned 12 indicators, potassium $\left(\mathrm{K}^{+}\right)$, magnesium $\left(\mathrm{Mg}^{2+}\right)$, calcium $\left(\mathrm{Ca}^{2+}\right)$, sulfate $\left(\mathrm{SO}_{4}{ }^{2-}\right)$, Secchi depth, etc., were measured, but the results on them were not shown because they were closely related to some of the above indicators. Vertical profiles of dissolved oxygen, etc., were also monitored, but the analysis in reference to EREs was not conducted. The data on water quality from Jan 1980 to Dec 2017 reported by Japan's National Institute for Environmental Studies (NIES) [25] were also used (only in Lake Kasumigaura).

Auto-sampling systems of water $50 \mathrm{~cm}$ below the surface were set at Sts. 2 (Lake Kasumigaura) and 3 (Lake Kitaura), and several indicators (Chla, COD, TN, TP, electric conductivity $[E C]$, and turbidity) were determined hourly. The analysis was automatically conducted based on the methods mentioned above.

Monthly water samplings have been done at the downstream points of the two lakes' main inflowing rivers. Since high-discharge days were avoided, these results are the information obtained during a dry weather period (i.e., the baseflow condition [BF]). The data on $\mathrm{COD}, \mathrm{TN}, \mathrm{NO}_{3}{ }^{-} \mathrm{N}$, $\mathrm{TP}$, and $\mathrm{PO}_{4}{ }^{3-}-\mathrm{P}$ of the water samples for the period from Jan 2005 to Dec 2017 were used for the further analysis. When considering the relationship between the river's and the lake's water quality, we assumed that the Sakura River (watershed area: $333.3 \mathrm{~km}^{2}$ ) and Shin River (15.8 $\mathrm{km}^{2}$ ) corresponded to St. 1 ; the Koise River $\left(218.1 \mathrm{~km}^{2}\right)$ and Sanno River $\left(12.8 \mathrm{~km}^{2}\right)$ corresponded to St. 2 ; and the Tomoe River $\left(128.4 \mathrm{~km}^{2}\right)$ and Hokota River $\left(43.9 \mathrm{~km}^{2}\right)$ corresponded to St. 3, and we calculated the averages weighted by the watershed areas.

Meteorological information (e.g., daily precipitation amount, daily averaged wind speed) at Tsuchiura (St. M1), Kakioka (St. M2), and Hokota (St. M3) (Fig. 1) was also used for the analysis with the respective lake monitoring stations (e.g., St. M1 corresponding to St. 1) [26]. The daily rainfall data at these stations from Jan 1980 to Dec 2017 were used to analyze the rainfall characteristics in these basins. In addition, daily discharge amounts at the downstream stations of the Sakura River (watershed area to this station: $\left.327.8 \mathrm{~km}^{2}\right)$, the Koise River $\left(147.0 \mathrm{~km}^{2}\right)$, and the Tomoe River $\left(111.0 \mathrm{~km}^{2}\right)$ for 2006-2015 were used to calculate the water runoff rates. Daily discharge amounts were calculated using hourly water-level data and the relationships between water level and water discharge rate at the respective stations.

\subsection{Analytical steps}

\subsubsection{Rainfall characteristics}

Each rainfall event was separated by the day(s) of no rainfall. The magnitude of rainfall events was evaluated by 
the percentiles of whole rainfall events at the respective stations (Supplementary Table 1). The rainfall amounts of $50 \mathrm{~mm}, 100 \mathrm{~mm}$, and $140 \mathrm{~mm}$ were the 90th, 98th, and 99th percentiles at St. M-1, the 88th, 97th, and 98th percentiles at St. M-2, and the 88th, 87th, and 99th percentiles at St. M-3, respectively. The boundaries of $\geqq 50 \mathrm{~mm}$ (around 90th percentile), $100 \mathrm{~mm}$ (around 97th percentile), and $140 \mathrm{~mm}$ (around 99th percentile) for large rainfall events were selected and used for the following analyses. Considering the number of rainfall events in this region, the rainfall of $>50 \mathrm{~mm}$ and that of $>140 \mathrm{~mm}$ occurred a few times per year and once a few years, respectively. To elucidate the temporal trend of rainfall characteristics, the annual precipitation amount and the annual numbers of large/extreme daily rainfall ( $\geqq 50,100,140 \mathrm{~mm}$ ) were compared between the first and second halves of the whole period (Supplementary Fig. 1 and Supplementary Table 2 as discussed below). Extremely large rainfall events ( $140 \mathrm{~mm}$ ) for 10 days (explained below) were also compared between the periods.

\subsubsection{Runoff rate and estimated water volume during large rainfall events}

The annual-averaged runoff rates of the Sakura, Koise and Tomoe Rivers were determined as annual discharge divided by annual rainfall amount and watershed area (Supplementary Table 3). Because water runoff in the inflowing rivers was attenuated within a few days after rainfall event, the water runoff rates for the respective rainfall events were calculated by sum of discharge during eight days after the rainfall event divided by rainfall amount for the period (total rainfall $\geqq 50 \mathrm{~mm}$ for the first three days) (Supplementary Table 3). The rainfall events which had $\geqq 10 \mathrm{~mm}$ rainfall during the five days before or after the first three days of the rainfall event were excluded because there would be effects of these rainfalls. We calculated the volumes that were retained to the sampling stations close to the main inflow rivers (Sts 1, 2, 3, 1-1, and 3-1) by using the bathymetric maps of the two lakes (Table 1) and compared these volumes with the water volume inflowing after 50,100 , and $140 \mathrm{~mm}$ of precipitation estimated using the above-calculated runoff rates for the respective watersheds.

\subsubsection{LREs and EREs in this study}

Based on Supplementary Table 1, rainfall events of $\geqq 50$ (around 90th percentile), 100 (larger than 95th percentile), and $140 \mathrm{~mm}$ (around 98th percentile) were considered large rainfall events (LREs) in this study. Out of LREs, we focused on the extreme rainfall events (EREs) to investigate their effects on lake water quality. As the EREs, Morabito et al. (2018) selected the rainfall events which had $\geqq 90^{\text {th }}$ percentile of the whole events from 0 to 7 days before the phytoplankton sampling. In contrast, De Eyto et al. (2016) reported the response of a humic lake ecosystem at the epicenter of a once in 250-year precipitation event. In this study, we used the highest threshold ( $\geqq 140 \mathrm{~mm}$ ) for EREs because typical effects of extremely large rainfall event would be expected. In addition, the events of $50-100 \mathrm{~mm}$ and those of 100-140 mm were indicated by LREs-1 and LREs-2, respectively.

To elucidate clearly the effect of LREs/EREs on water quality at the stations close to the inflowing rivers (Sts. 1, $2,3,1-1$, and 3-1), the correlation coefficients between water quality and rainfall amount were then used to compare three different periods $(5,10$, and 15 days) before water quality monitoring. Then, the period giving the highest correlations was used to choose the LREs and EREs.

\subsubsection{Analysis of LREs/EREs effects on lake water quality}

After LREs/EREs, some indicators of water quality show the recovery to the state before the events through ordinary biogeochemical processes (e.g., algal growth, mixing with downstream water bodies). For example, the washaway of phytoplankton and/or shunt of specially low/high chemical substances by river runoff waters would be expected. Low/high values of these water qualities indicate the proof of LREs/EREs effects, and the degree departed from the ordinary state could be evaluated by their percentiles.
Table 1 Water volumes to the targeted stations and inflow water volumes caused by extreme rainfall events (EREs) and large rainfall events (LREs)

\begin{tabular}{llllll}
\hline & $\begin{array}{l}\text { Area to the } \\
\text { station }(\mathrm{A}) \\
\left(\mathrm{km}^{2}\right)\end{array}$ & $\begin{array}{l}\text { Volume to the } \\
\text { station }(\mathrm{V})\left(10^{6}\right. \\
\left.\mathrm{m}^{3}\right)\end{array}$ & $\begin{array}{l}\text { Watershed area to } \\
\text { the station }(\mathrm{Aw}) \\
\left(\mathrm{km}^{2}\right)\end{array}$ & $\begin{array}{l}\text { Inflow water } \\
\text { volume*1 (Vin) } \\
\left(10^{6} \mathrm{~m}^{3}\right)\end{array}$ & Vin/V \\
\hline St. 1 & 1.0 & 2.6 & 369 & $24.3(8.7,17.3)$ & $9.3(3.3,6.7)$ \\
St. 2 & 1.5 & 1.9 & 310 & $19.1(6.8,13.6)$ & $10.0(3.6,7.2)$ \\
St. 3 & 1.4 & 1.7 & 186 & $10.9(3.9,7.8)$ & $6.4(2.3,4.6)$ \\
St. 1-1 & 9.4 & 27.7 & 406 & $26.7(9.5,19.1)$ & $0.96(0.34,0.69)$ \\
St. 3-1 & 4.2 & 10.1 & 196 & $11.5(4.1,8.2)$ & $1.1(0.41,0.82)$ \\
\hline
\end{tabular}

*1: Rainfall amount $(R)=140(50,100) \mathrm{mm}$, water runoff rate (wrr) $=0.47$ (St. 1 and St. 1-1), 0.44 (St. 2), 0.42 (St. 3 and St. $3-1$ ), Vin $=A w^{*} R^{*}$ wrr 
Morabito et al. (2018) used the 75th percentile values for chemical and biological variables to analyze the influence of precipitation on them. In this study, we used the $25^{\text {th }}$ percentile values for distinguishing the direct rainfall influence.

\subsection{Statistical methods}

We determined the correlations, differences between the means ( $t$ test), and differences between the ratios for significance at the level of $p=0.05\left({ }^{*}\right)$ or $p=0.01\left(^{* *}\right)$ with the use of Excel Statistics for 2016 (BellCurve Social Survey Research Information Co., Tokyo) and OriginPro 2017 J (OriginLab. Corp., Northampton, USA).

\section{Results}

\subsection{The relationship between the rainfall amounts and the water quality}

The amounts of rainfall for 5,10 , and 15 days before the lake water-quality monitoring were calculated, and the correlations between these rainfall amounts and the lake water quality were compared. The highest correlations were observed mostly for the 10-day periods among the $5-, 10-$, and 15-day periods, respectively; for examples, the correlation with $\mathrm{Na}^{+}$at St. $1: \mathrm{r}=-0.21^{* *}, \mathrm{r}=-0.35^{* *}$, $r=-0.34^{* *}$; with $\mathrm{Na}^{+}$at St. 2: $r=-0.21^{* *}, r=-0.35^{* *}$, $r=-0.34^{* *}$; with $\mathrm{Na}^{+}$at St. 3: $r=-0.45^{* *}, r=-0.58^{* *}$, $r=-0.04$; with Si at St. 3: $r=-0.26^{* *}, r=-0.31^{* *}, r=-0.08$. We therefore used the rainfall amount for 10 days before the lake water-quality monitoring for the subsequent analysis.

In general, negative correlations between the rainfall amounts and the lake water quality were observed for $\mathrm{Na}^{+}$, $\mathrm{Cl}^{-}, \mathrm{Chla}$, and COD, and a positive correlation was observed for $\mathrm{PO}_{4}{ }^{3-}$-P. Other indicators showed different behaviors at the three stations (Sts. 1, 2, and 3; Fig. 2, Supplementary Figs. 2, 3, and 4). The correlations were less clear at the stations that were not as close to the influent rivers (Sts. 1-1 and 3-1; e.g., Supplementary Fig. 5 for St. 1-1).

\subsection{Assessment of the direct rainfall effects}

As shown in Fig. 2, clear effects on the water quality (e.g., low $\mathrm{Na}^{+}, \mathrm{Cl}^{-}$, and $\mathrm{Chla}$ ) were usually observed for the sampling days that have experienced large rainfall amounts prior to 10 days before the lake water-quality monitoring, but unclear effects were also observed sometimes. We could expect that the clear effects indicated negligible changes after inflowing into the lakes occurred; that is, the clear effects had implications for river water quality during the LREs/EREs, and that the unclear effects indicated significant changes in the lakes, e.g., algal growth and mixing with downstream lake water. We thus chose $\mathrm{Na}^{+}, \mathrm{Cl}^{-}$, and Chla as the indicators for evaluating the in-lake changes, and we used the values less than 25th percentiles to judge that the effect of rainfall was significant.

We thus classified the samples obtained after the rainfall amount $\geq 140 \mathrm{~mm}$ (EREs) into group 1 (G1; i.e., the $\mathrm{Na}^{+}$, $\mathrm{Cl}^{-}$, and Chla values were $\leq 25$ th percentiles) and group 2 (G2; any of them $>25$ th percentiles) (Table 2). In this study, $\mathrm{G} 1$ was defined as the status in which all three percentiles were $\leq 25$ th percentiles, and $\mathrm{G} 2$ was the other samples; anyhow, the same classification results as Table 2 were obtained when we changed the threshold from $\leq 20$ th percentiles to that $\leq 35$ th percentiles. We compared the rainfall patterns for the respective events between $\mathrm{G} 1$ and G2; clear differences were not observed (data not shown). The effects of the preceding rainfall events (LREs/EREs) on the classification into $\mathrm{G} 1$ or $\mathrm{G} 2$ were not clear (Table 2). The samples after the rainfalls LREs- 1 and LREs- 2 were also investigated; the changes in the increased numbers of $\mathrm{G} 1$ samples were small, but those of $\mathrm{G} 2$ were markedly changed (Table 3; proportion of G1 in all cases significantly higher in EREs compared to LREs-1, LREs-2 $[p<0.05])$. Although EREs did not occur from Mar to Jun (Table 2), the separation of a year into the period of Jun to Sep and that of Oct to May is examined in Table 3 considering the occurrence frequencies of LREs-1/LREs- 2 and lake thermal conditions (air/water temperatures). We thus calculated the averaged ( \pm standard deviation [SD]) values of water quality for G1 of EREs, G2 of EREs, and others, respectively, using the 'rainfall amount $\geq 140 \mathrm{~mm}$ ' threshold, i.e., EREs events (Table 4; Supplementary Table 4). At all the three stations, the values of $\mathrm{COD}, \mathrm{DCOD}, \mathrm{Na}^{+}, \mathrm{Cl}^{-}$, and Chla were low in the $\mathrm{G} 1$ group compared to those in the $\mathrm{G} 2$ group and others, whereas the values of $\mathrm{TN}$ and $\mathrm{PO}_{4}{ }^{3-}-\mathrm{P}$ (and $\mathrm{NO}_{3}{ }^{-}-\mathrm{N}$ at Sts. 1 and 2) were high in $\mathrm{G} 1$ (significant difference seen in $\mathrm{COD}, \mathrm{TN}, \mathrm{NO}_{3}-\mathrm{N}, \mathrm{TOC}, \mathrm{Na}^{+}, \mathrm{Cl}^{-}$, Chla).

Similar values of water quality during $\operatorname{EREs}(\geq 140 \mathrm{~mm})$ were obtained from the NIES database (Supplementary Table 5). Four samples at St. 1 and five samples at St. 2 belonged to the $\mathrm{G} 1$ category (both percentiles of Chla and $\mathrm{EC} \leq 25$ th percentile). No sample at St. 1 and two samples at St. 2 belonged to $\mathrm{G} 2$.

\subsection{The relationship between water quality in dry weather and that during large rainfall events}

Regarding the values of $\mathrm{COD}, \mathrm{TP}$, and $\mathrm{PO}_{4}{ }^{3-}-\mathrm{P}$, the values in $\mathrm{G} 1$ of EREs were slightly higher than their annul-averaged values of river water quality in the $\mathrm{BF}$ condition, whereas the values of $\mathrm{TN}$ and $\mathrm{NO}_{3}{ }^{-} \mathrm{N}$ in $\mathrm{G} 1$ of EREs and the $\mathrm{BF}$ condition were nearly the same (Fig. 3a). In the case of 

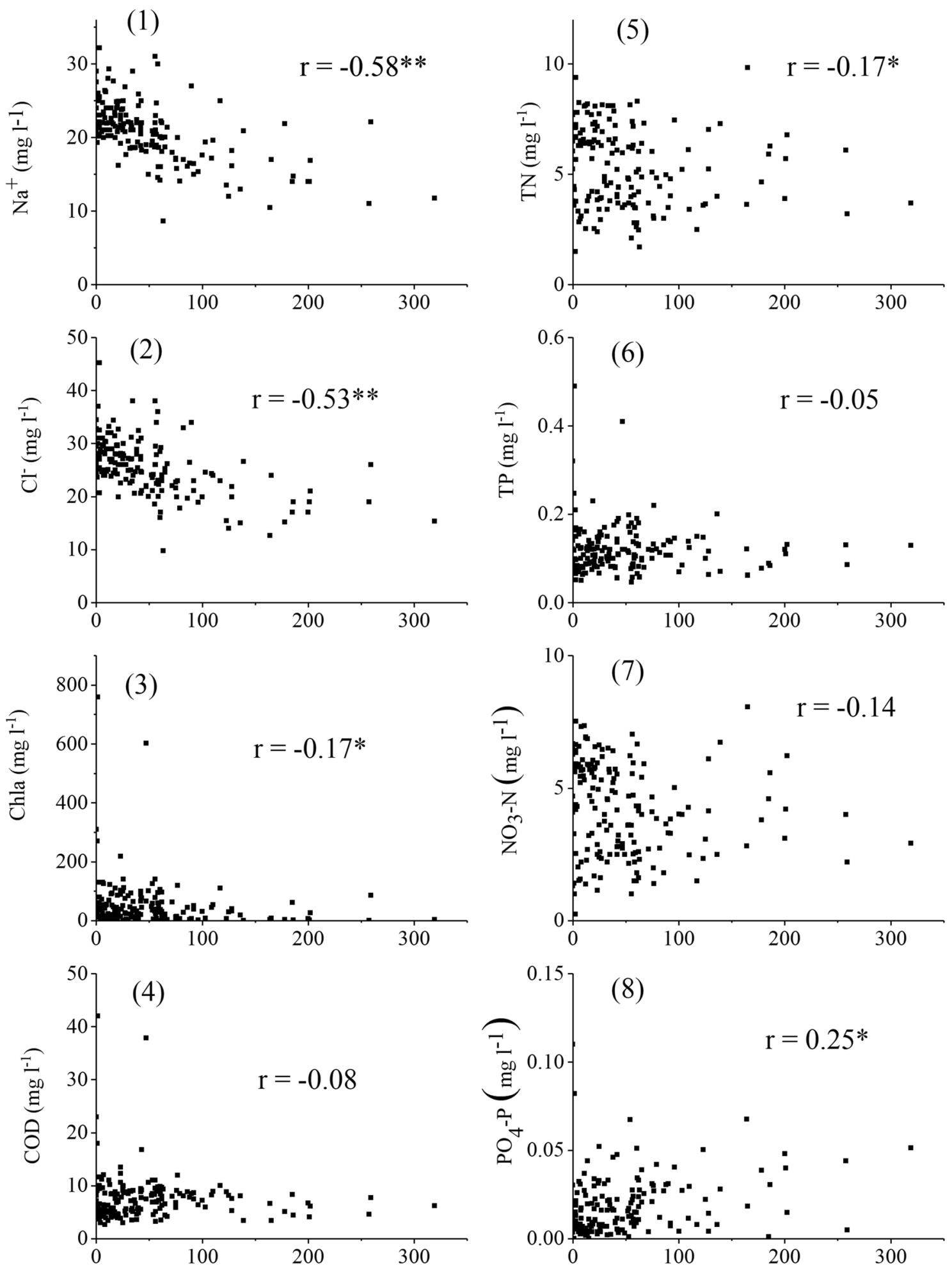

Sum of precipitation amount for previous 10 days $(\mathrm{mm})$

Fig. 2 The relationships between the sum of the precipitation amounts for 10 days prior to water sampling and the water-quality indicators at St. 3. (1) $\mathrm{Na}^{+}$, (2) $\mathrm{Cl}^{-}$, (3) Chla, (4) COD, (5) TN, (6) TP, (7) $\mathrm{NO}_{3}-\mathrm{N}$, and (8) $\mathrm{PO}_{4}-\mathrm{P}$ 
Table 2 Characteristics of the $\mathrm{Na}^{+}, \mathrm{Cl}^{-}$, and Chla concentrations on the sampling days after extreme rainfall events $(\geq 140 \mathrm{~mm}$ during the 10 preceding days)

\begin{tabular}{|c|c|c|c|c|c|c|c|}
\hline \multirow[t]{2}{*}{ Station } & \multirow[t]{2}{*}{ Group } & \multirow[t]{2}{*}{ Sampling date } & \multirow{2}{*}{$\begin{array}{l}\text { Rainfall amount }(\mathrm{mm}) \text { before } 10 \text { days } \\
\text { to the date (preceding events) }\end{array}$} & \multicolumn{3}{|c|}{ Percentile $(n=166)$} & \multirow[t]{2}{*}{ SS/SSmax } \\
\hline & & & & $\mathrm{Na}^{+}$ & $\mathrm{Cl}^{-}$ & Chlorophyll a & \\
\hline \multirow[t]{9}{*}{ St. 1} & \multirow[t]{5}{*}{$\mathrm{G} 1$} & $2006 / 10 / 13$ & 142 (LRE-1) & 2 & 2 & 20 & 0.25 \\
\hline & & $2007 / 1 / 5$ & 144 & 4 & 3 & 3 & 0.28 \\
\hline & & 2013/10/19 & 174 & 7 & 11 & 14 & 0.39 \\
\hline & & $2014 / 10 / 10$ & 201 & 18 & 1 & 14 & 0.21 \\
\hline & & 2019/10/31 & 179 (ERE, LRE-1) & 1 & 2 & 1 & 0.18 \\
\hline & \multirow[t]{4}{*}{$\mathrm{G} 2$} & $2006 / 7 / 27$ & 149 & 10 & 15 & 72 & 0.28 \\
\hline & & $2007 / 9 / 14$ & 143 & 6 & 7 & 66 & 0.26 \\
\hline & & 2015/9/19 & 212 & 3 & 4 & 40 & 0.21 \\
\hline & & $2016 / 8 / 26$ & 250 & 73 & 77 & 82 & 0.40 \\
\hline \multirow[t]{9}{*}{ St. 2} & \multirow[t]{3}{*}{ G1 } & $2007 / 1 / 5$ & 145 & 4 & 7 & 3 & 0.29 \\
\hline & & $2014 / 10 / 10$ & 282 & 5 & 1 & 5 & 0.31 \\
\hline & & 2019/10/31 & 144 (ERE, LRE-1) & 1 & 1 & 2 & 0.23 \\
\hline & \multirow[t]{6}{*}{$\mathrm{G} 2$} & $2006 / 7 / 27$ & 173 & 25 & 43 & 55 & 0.35 \\
\hline & & $2007 / 9 / 14$ & 155 & 25 & 36 & 65 & 0.35 \\
\hline & & 2015/9/19 & 229 & 5 & 6 & 36 & 0.23 \\
\hline & & $2016 / 8 / 26$ & 324 & 88 & 87 & 77 & 0.35 \\
\hline & & 2016/9/16 & 149 (ERE) & 7 & 27 & 60 & 0.31 \\
\hline & & 2017/7/13 & 170 & 78 & 62 & 37 & 0.53 \\
\hline \multirow[t]{10}{*}{ St. 3} & \multirow[t]{7}{*}{ G1 } & $2007 / 1 / 5$ & 165 & 17 & 20 & 18 & 0.10 \\
\hline & & 2013/10/19 & 319 (LRE-1) & 2 & 4 & 8 & 0.22 \\
\hline & & $2014 / 2 / 18$ & 186 & 8 & 10 & 3 & 0.09 \\
\hline & & $2014 / 10 / 10$ & 178 & 3 & 3 & 10 & 0.04 \\
\hline & & 2015/9/19 & 164 & 1 & 1 & 8 & 0.10 \\
\hline & & $2018 / 9 / 27$ & 200 & 5 & 5 & 14 & 0.09 \\
\hline & & 2019/10/31 & 258 (LRE-2) & 2 & 9 & 1 & 0.11 \\
\hline & \multirow[t]{3}{*}{$\mathrm{G} 2$} & $2006 / 7 / 27$ & 185 (LRE-1) & 5 & 5 & 73 & 0.10 \\
\hline & & $2006 / 10 / 13$ & 202 (LRE-1) & 16 & 17 & 40 & 0.11 \\
\hline & & $2016 / 8 / 26$ & 259 & 68 & 51 & 83 & 0.11 \\
\hline
\end{tabular}

For the respective indices $\left(\mathrm{Na}^{+}, \mathrm{Cl}^{-}\right.$, and Chla), all data $(\mathrm{n}=166)$ were ordered from the minimum value to the maximum value at each station, and the percentiles were calculated. G1 satisfies the condition that all the three percentiles are $\leq 25^{\text {th }}$ percentile. G2: others. Parentheses in the column of "Rainfall amount before 10 days to the date" indicate the information on the large rainfall events observed during the days before the target event in the month and the preceding month (nothing for no event). Regarding SS, the ratio to SSmax at the respective stations was calculated (SSmax $=57,62$, and $105 \mathrm{mg} \mathrm{I}^{-1}$ at Sts. 1, 2, and 3)

$\mathrm{BF}$ values during the period from Oct to Feb (when $\mathrm{G} 1$ of EREs happened), the values of $\mathrm{COD}, \mathrm{TP}$, and $\mathrm{PO}_{4}{ }^{3-}-\mathrm{P}$ in $\mathrm{G} 1$ of EREs were roughly twofold higher than those in the $\mathrm{BF}$ condition, and the values of $\mathrm{TN}$ and $\mathrm{NO}_{3}{ }^{-} \mathrm{N}$ in $\mathrm{G} 1$ of EREs were $~ 50 \%-100 \%$ of those in the BF condition (Fig. 3b). We are certain that seasonal changes in the quality of river water (i.e., higher $\mathrm{TN}$ and $\mathrm{NO}_{3}{ }^{-}-\mathrm{N}$ and lower $\mathrm{COD}$, TP, and $\mathrm{PO}_{4}{ }^{3-}-\mathrm{P}$ values from fall to winter compared to other seasons; data not shown), brought about these results.

\subsection{Influences on lake water quality}

Two examples of water-quality changes between before and after EREs are provided in Fig. 4. At both of the two
EREs, the values of $\mathrm{Cl}^{-}$, Chla, and COD decreased and those of dissolved nutrient $\left(\mathrm{NO}_{3}{ }^{-}-\mathrm{N}, \mathrm{PO}_{4}{ }^{3-}-\mathrm{P}\right)$ increased through the EREs clearly at the stations close to the inflowing rivers (Sts. 1 and 3) and less clearly at the more pelagic stations (Sts. 1-1 and 3-1). Less-clear changes were observed for TN and TP. These tendencies were similar to those listed in Table 4 (G1 of EREs vs. "others").

The changes at the further downstream stations due to the EREs in Oct 2019 and Jul 2016 are illustrated in Supplementary Figs. 6 and 7, respectively. The effects of the EREs decreased with increasing distance from the inflowing rivers. A period $>3$ months was needed for these values to return to the original states. After the ERE in Oct 2019 (Supplementary Fig. 6), dissolved nutrients $\left(\mathrm{NO}_{3}{ }^{-} \mathrm{-}\right.$, 
Table 3 Rainfall event numbers classified to $\mathrm{G} 1$ (Cases $\mathrm{G} 1 ; \mathrm{Na}^{+}, \mathrm{Cl}^{-}$, and Chla values were $\leq 25$ th percentiles) and to $\mathrm{G} 2$ (Cases $\mathrm{G} 2$; others) (proportion of $\mathrm{G} 1$ in all cases), and Cases $\mathrm{G} 1$ and $\mathrm{G} 2$ occurred for Jun-Sep

\begin{tabular}{lllll}
\hline & & $\begin{array}{l}\text { Cases G1/ } \\
\text { Cases G2 } \\
(\text { G1\%) }\end{array}$ & $\begin{array}{l}\text { Cases G1 in } \\
\text { Jun-Sep/Cases } \\
\text { G1 }\end{array}$ & $\begin{array}{l}\text { Cases G2 in } \\
\text { Jun-Sep/Cases } \\
\text { G2 }\end{array}$ \\
\hline Rainfall events $\geq 140 \mathrm{~mm}$ EREs & St. 1 & $5 / 4(56 \%)$ & $0 / 5$ & $4 / 4$ \\
& St. 2 & $3 / 6(33 \%)$ & $0 / 3$ & $6 / 6$ \\
& St. 3 & $7 / 3(70 \%)$ & $2 / 7$ & $2 / 3$ \\
& St. 1, 2, 3 & $15 / 13(54 \%)$ & $2 / 15$ & $12 / 13$ \\
Rainfall events $\geq 100 \mathrm{~mm},<140 \mathrm{~mm}$ LREs-2 2 St. 1 & $1 / 7(13 \%)$ & $0 / 1$ & $4 / 7$ \\
& St. 2 & $2 / 8(20 \%)$ & $0 / 2$ & $4 / 8$ \\
& St. 3 & $1 / 9(10 \%)$ & $1 / 1$ & $4 / 9$ \\
& St. 1, 2, 3 & $4 / 24(14 \%)$ & $1 / 4$ & $12 / 24$ \\
Rainfall events $\geq 50 \mathrm{~mm},<100 \mathrm{~mm}$ LREs-1 & St. 1 & $5 / 29(15 \%)$ & $2 / 5$ & $13 / 29$ \\
& St. 2 & $2 / 25(7 \%)$ & $0 / 2$ & $10 / 25$ \\
& St. 3 & $3 / 40(7 \%)$ & $0 / 3$ & $16 / 40$ \\
& St. 1, 2, 3 & $10 / 94(10 \%)$ & $2 / 10$ & $39 / 94$ \\
\hline
\end{tabular}

$\left.\mathrm{PO}_{4}{ }^{3-}-\mathrm{P}\right)$ to a large extent remained in the lake water because their primary production was suppressed by low temperature (low Chla after Nov; the air temperature at St. M1 averaged for 10 days before the water sampling day on Oct 31,2019 was $16.5^{\circ} \mathrm{C}$ ) and high turbidity (data not shown). In contrast, dissolved nutrients decreased or did not change after the ERE in Aug 2016 (Supplementary Fig. 7), because highly active primary production occurred (high Chla in Aug; averaged air temperature: $26.7^{\circ} \mathrm{C}$ ). These differences indicate that the effects of EREs on in-lake processes depend on the season.

\section{Discussion}

\subsection{Implications for river water quality during extreme/large rainfall events}

In this study, we focused on the water quality near the mouth of influent rivers, and then the main effect of LREs/ EREs would be not growth of algal blooms by supply of nutrients [12] but flushing of phytoplankton communities $[13,14]$. As indicated in Table 1, the water to the sampling stations was certainly exchanged by the river water inflowing during EREs (more than six times water volume to the targeted station). However, rivers' water quality changes markedly during such periods, and a question thus arises; do the monitoring data in the lake precisely reflect the averaged river water quality during LREs/EREs? We observed that the water-quality data varied after EREs (e.g., Oct 2019; the daily averaged values are shown in Fig. 5). During that month, two LREs/EREs occurred (Period 1: 11-12 Oct; $199.5 \mathrm{~mm}$ at St. M2, $126.5 \mathrm{~mm}$ at St. M3; Period 2: 25-26 Oct; $85.0 \mathrm{~mm}$ at St. M2, $202.0 \mathrm{~mm}$ at St. M3). The degrees of variations were not so large (the coefficient of variation of hourly data during 5 days after the events was usually $<15 \%$; Supplementary Table 6). We thus conclude that the monitoring data after EREs roughly reflect the averaged water quality of inflowing water when this water volume is more than six times of the volume to the station.

On the other hand, there is a possibility of in-lake changes. To check this possibility, $\leq 25$ th percentiles of $\mathrm{Na}^{+}$, $\mathrm{Cl}^{-}$, and Chla were used as the thresholds, but from $\leq 20$ th to $\leq 35$ th percentiles give the same classification for EREs, indicating that such level of thresholds could distinguish the water quality after in-lake change. Generally, the events after EREs classified as G1 happened during the months from Oct to May, whereas those classified as G2 occurred during the months from Jun to Sep (Table 3). In the NISE database, similar features were observed (G1 of EREs at St. 1 happened once in Aug, once in Sep, and twice in Oct; $G 1$ at St. 2 once in Aug, once in Sep, and three times in Oct; $\mathrm{G} 2$ at St. 2 once in Jun, once in Jul). In the events of active primary production occurred under hot conditions, then a high value of Chla was expected immediately after the EREs. In addition, higher mineral concentrations were ordinarily observed at downstream stations in the lakes, probably due to the longitudinal distributions of the atmospheric mineral supply and evaporation. The mineral concentrations in influent river water were rather lower compared to those of the lake water [27]. Thus, the high $\mathrm{Na}^{+}$and $\mathrm{Cl}^{-}$concentrations that we observed after EREs (sometimes in G2) indicate the longitudinal mixing of water and that the lake water quality does not represent the river water quality during EREs. In the events after LREs, G1 rarely occurred from Jun to Sep similarly to EREs, but $\mathrm{G} 2$ often occurred during the months from Oct to May differently from EREs (Table 3; proportion of G2 in Jun-Sep: 0.92 for EREs significantly $[p<0.05]$ higher compared to 


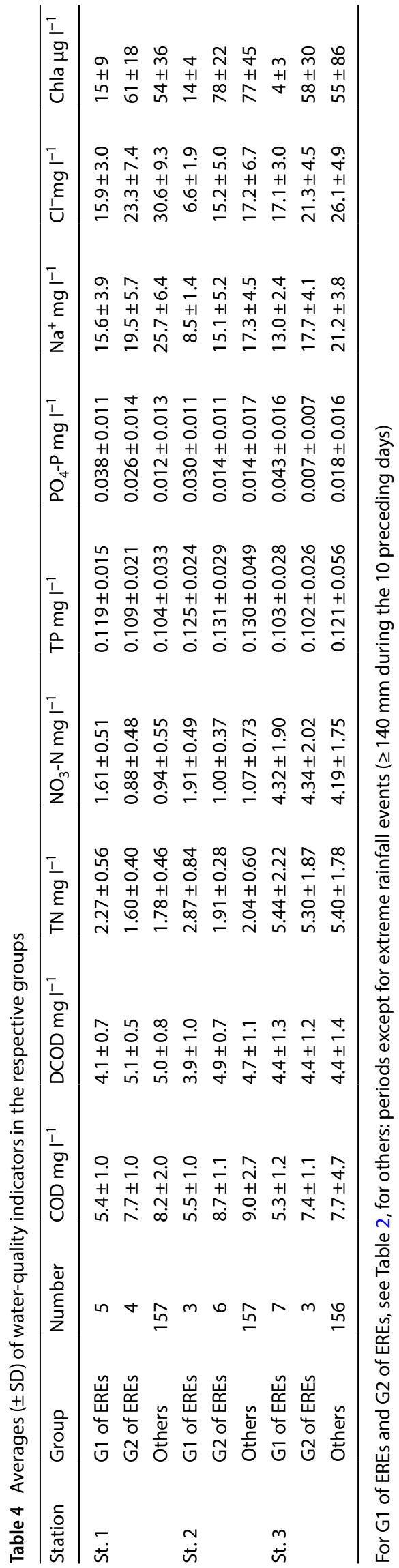

0.50 for LERs- 2 and 0.41 for LERs- 1 ). Because of small proportions of $\mathrm{G} 1$ for LREs events (Table 3), fast recoveries of algal production usually occurred even at the stations near the influent rivers and the observed water quality does not precisely reflect the averaged river water quality during LREs.

Ebise [20] proposed the estimation models for runoff loads during rainfall event based on lots of minute measurements. When we used the model for rural rivers in the Ebise [20] study, we observed that the estimated mean concentrations were close to our present data (the averages of three stations belonging to $\mathrm{G} 1$ of EREs), but our results were generally a little higher than the model (Table 5). This is probably because the surveys of Ebise [20] focused mainly on the upstream parts of rural rivers. It is thus apparent that the lake water quality near the inflowing rivers just after EREs describes the averaged quality of the inflowed river water.

\subsection{Differences in water quality between the EREs and the BF condition}

As shown in Fig. 3, tendencies of positive correlations between the $\mathrm{G} 1$ of EREs and the BF condition were observed for $\mathrm{TN}$ and $\mathrm{NO}_{3}{ }^{-}-\mathrm{N}$. Large differences among the stations may have resulted in these clear correlations. Such spatial correlations among five forest regions in Japan (Aichi, Kochi, Mie, Nagano, Tokyo) were observed for various water-quality indicators (nutrients, suspended solids, etc.) [19]. Natural factors (e.g., geological and geographical factors) and artificial factors (load discharge, human impact, etc.) might affect the water quality during both the BF condition and EREs.

We also observed that the values of COD, TP, and $\mathrm{PO}_{4}{ }^{3-}-\mathrm{P}$ for $\mathrm{G} 1$ of EREs were approx. twofold higher than those in the $\mathrm{BF}$, whereas the values of $\mathrm{TN}$ and $\mathrm{NO}_{3}{ }^{-} \mathrm{N}$ for G1 of EREs were $50 \%-100 \%$ of those in the BF condition from Oct to Feb (Fig. 3 (2)). Zhang et al. [19] reported that higher concentrations of dissolved organic carbon (DOC) and dissolved inorganic nitrogen (DIN) in EREs compared to the BF condition (and a similar level for dissolved total phosphorus [DTP]) in water samples they obtained from forested watersheds. Abell et al. [28] reported that they observed higher TN and TP values and lower DIN values in EREs compared to the $\mathrm{BF}$ condition $\left(\mathrm{PO}_{4}{ }^{3-}-\mathrm{P}\right.$ was unrelated to the water discharge rate) based on their high-frequency sampling of two major stream inflows to a large eutrophic lake. According to the logarithmic regression models for estimating discharge loads indicated that the exponents were larger than unity for suspended solids (SS), COD, and $T P$, (i.e., their concentrations increased with discharge) and lower than unity for TN, DTN, and DTP (i.e., their concentrations decreased with discharge) [20]. In general, total 

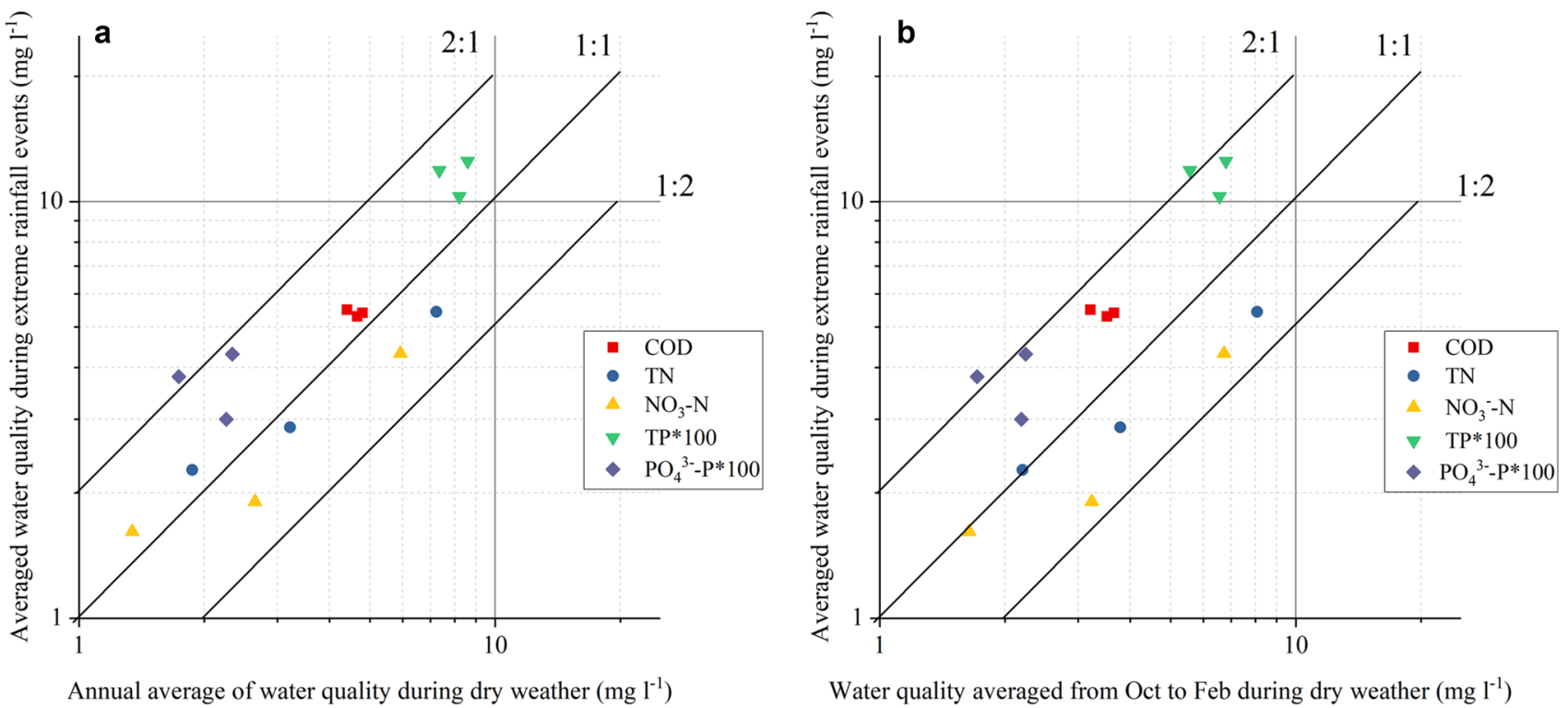

Water quality averaged from Oct to Feb during dry weather ( $\mathrm{mg} \mathrm{l}^{-1}$ )

Fig. 3 Water quality comparison: monitoring at inflowing rivers during dry weather (baseflow condition) versus the lake water quality after extreme rainfall events (G1 of EREs). a Annual average at inflowing rivers. b Average of Oct to Feb monitoring

and particulate nutrients increase with discharge, and dissolved nutrients decrease with discharge from many types of watershed. Our TN and $\mathrm{PO}_{4}{ }^{3-}$ - $\mathrm{P}$ results should thus be reexamined with more field data.

\subsection{The effects of LREs/EREs on lake water quality}

The effects of LREs/EREs on lake water quality can be expected to depend on the rainfall amount, the distance from the inflow river, the water quality, the season, and more. The above discussion related to the difference between $\mathrm{G} 1$ and $\mathrm{G} 2$ of EREs (as mentioned in Tables 2 and 4, Supplementary Figs. 6 and 7) concerned the season as a factor; i.e., the lake's state of primary production and the subsequently temporal and longitudinal changes in Chla, COD, and dissolved nutrients. In the case of TP (less clearly for TN), the release from sediments [29] and the deposition of particulate components flowing during LREs/EREs [21] might affect the changes.

Using weekly data for a 16-year period in a subtropical reservoir, Harris and Baxter [30] indicated that the phytoplankton biomass tended to be depressed for approx. 3 months after individual storm events, and the dominant species changed from cyanobacteria to diatoms. The longer delay period observed in that reservoir is probably attributable to seasonal cycles of stratification. Using highfrequency water sampling and a robotic system with several sensors, Abell and Hamilton [31] reported fine-scale spatial and temporal variations in the transition zone between a stream and a large eutrophic lake during a summer rain event. They noted that the Chla concentrations in the transition zone were generally diluted by the stream, although hot spots (10-30 m wide) of high concentrations moved rapidly. They also developed a three-dimensional hydrodynamic-ecological model which possibly may describe the spatial and temporal variability of water quality due to rainfall-induced events. Without such a model, overall evaluations of the effects of LREs/EREs on lake water quality would be difficult.

The use of a remote sensing technique with satellite imaginary could contribute to our understanding of the dynamics induced by heavy rainfall events. Zhang et al. [32] monitored the river TSM (total suspended matter) plume induced by heavy rainfall events in China's Lake Taihu using Moderate Resolution Imaging Spectroradiometer (MODIS) $250 \mathrm{~m}$ imagery. A significantly positive correlation between the TSM plume area and the rainfall amount in LREs/EREs was observed. Using Landsat-8 OLI and Sentinel-2A information for Lake Utah in the USA, Page et al. [33] reported the spatio-temporal development of a harmful cyanobacterial algal bloom. A complex interaction between the landscape, climate conditions (LREs/ EREs, etc.), and water quality was suggested as a supportive environment for triggering the blooms.

Du et al. [34] analyzed the temporospatial dynamics of water quality and its response to river flow in one estuary of Lake Taihu based on Geostationary Ocean Color Imager (GOCI) imagery. They reported that high flow rates mainly played a dilution role for the Chla concentration, and that the erosion of the surface soil via rainfall was a major source of TSM to the estuary. A remote sensing technique could describe temporospatial changes in 

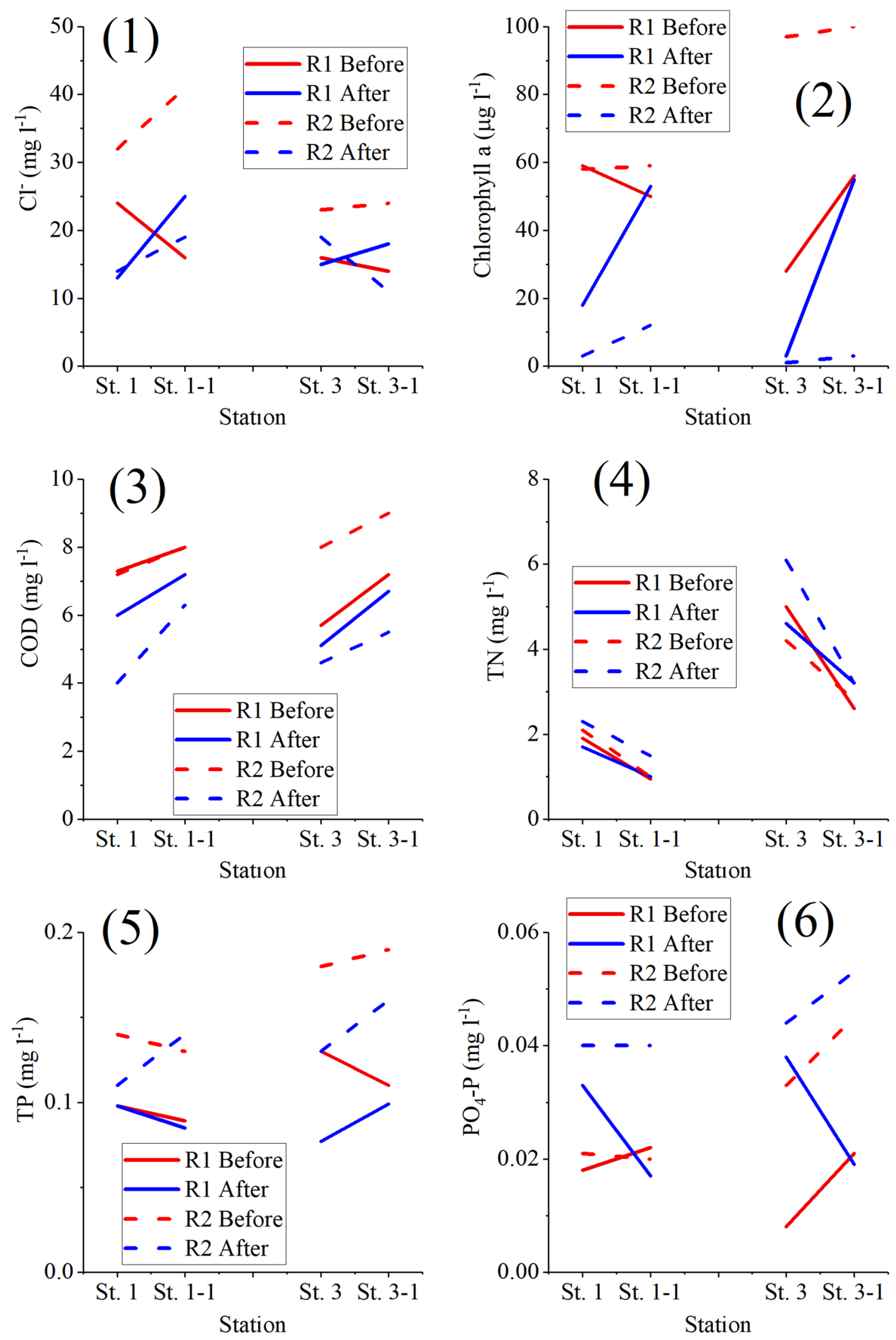

Fig. 4 Changes in the water quality before and after extreme rainfall events at the stations close to inflowing rivers. For R1, before: Sep 9, 2014, after: Oct 10, 2014 (rainfall amount for 10 days before

the latter monitoring day: $201 \mathrm{~mm}$ for St. M1, $178 \mathrm{~mm}$ for St. M3). For R2, before: Sep 25, 2019, after: Oct 31, 2019 (179 mm, 258 mm, respectively) 

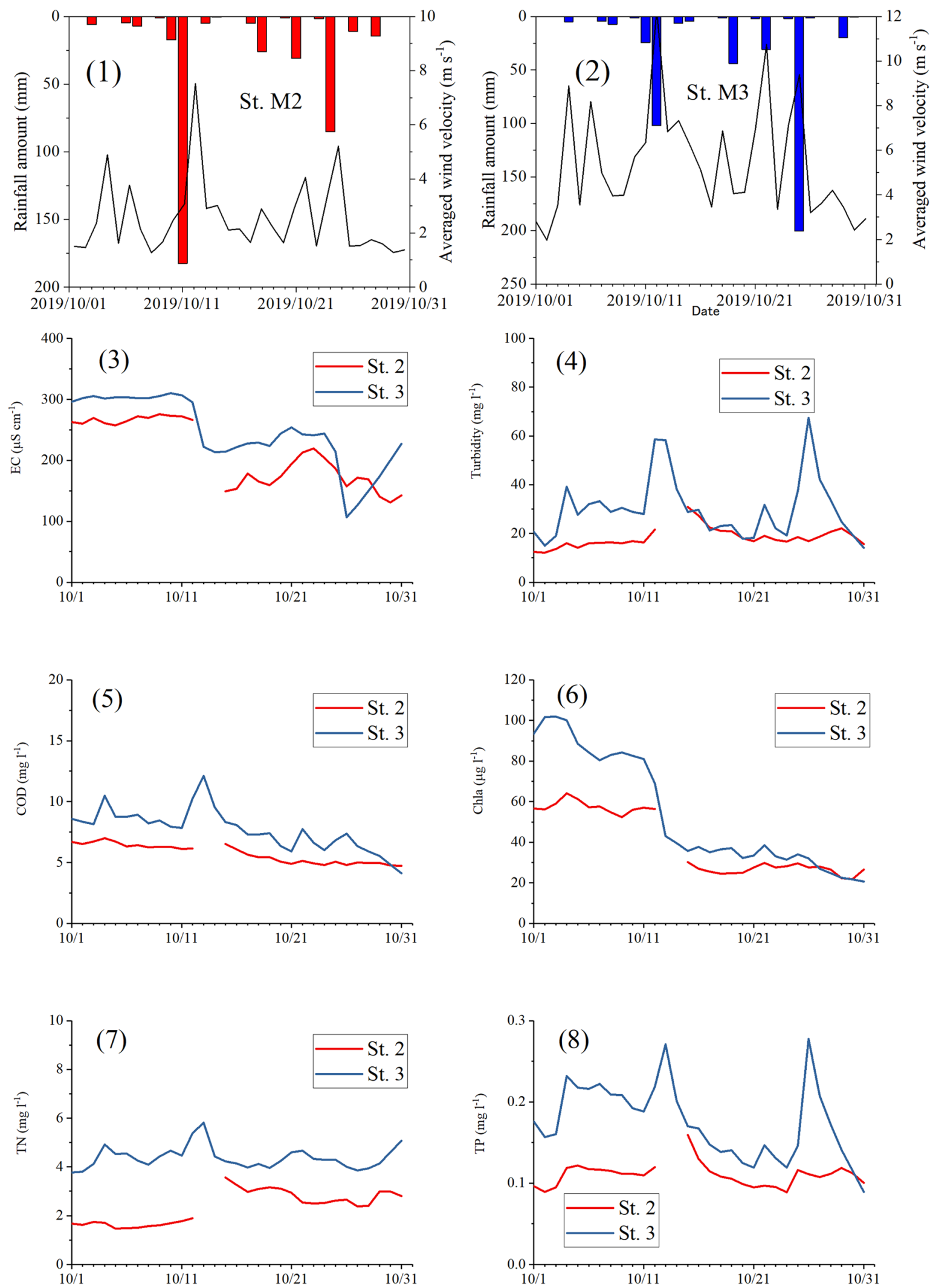

Fig. 5 Changes in meteorological parameters and water quality measured by the continuous monitoring system during Oct 2019. (1) The daily precipitation and maximum wind velocity at St. M2. (2)

The daily precipitation and maximum wind velocity at St. M3; (3) EC, (4) turbidity, (5) COD, (6) Chla, (7) TN, and (8) TP 
Table 5 The observed water quality during extreme rainfall events (the present study) $\left(\mathrm{mg} \mathrm{l}^{-1}\right)$ versus the water quality predicted by the runoff model $\left(\mathrm{mg} \mathrm{l}^{-1}\right)$

\begin{tabular}{lll}
\hline & $\begin{array}{l}\text { Average of St. 1, St. 2, and St. 3 } \\
\text { in G1 for EREs }\end{array}$ & Model estimation \\
\hline $\mathrm{COD}$ & 5.4 & 3.9 \\
$\mathrm{DCOD}$ & 4.1 & 3.7 \\
$\mathrm{TN}$ & 3.5 & 3.5 \\
$\mathrm{NO}_{3}-\mathrm{N}$ & 2.6 & 2.0 (DTN) \\
$\mathrm{TP}$ & 0.12 & 0.06 \\
$\mathrm{PO}_{4}-\mathrm{P}$ & 0.04 & 0.04 (DTP) \\
\hline
\end{tabular}

The model for the rural rivers in Type-2 (Ebise [20]) was used. The water discharge rate was calculated with the rainfall amount: $200 \mathrm{~mm}$ (because the average of rainfall amounts for G1 of EREs was $192 \pm 54 \mathrm{~mm}$ in Table 2) and 0.45 as the runoff coefficient

TSM, Chla, etc., after LREs/EREs, but it cannot provide the information on colorless substances. Thus, a combination of remote sensing, sensor monitoring, and hydrodynamic-ecological model would provide a new research for understanding the effects of LREs/EREs on lake water quality.

As shown in Supplementary Fig. 1 and Supplementary Table 2 , the frequencies of daily rainfalls $\geqq 50 \mathrm{~mm}$ and $\geqq 100 \mathrm{~mm}$ have recently increased at several stations in our study area (the frequency of extreme rainfall events $\geqq 140 \mathrm{~mm}$ for 10 days increased, but insignificantly), although the annual rainfall amount showed an insignificant change. It has not been determined whether global warming caused or contributed to this change. In shallow lakes, extreme weather events, (e.g., flashier rainfalls, prolonged droughts, and stronger tropical cyclones) can result in large amounts of runoff, sediment resuspension, resultant increases in dissolved nutrients, and the promotion or suppression of cyanobacterial blooms [35]. In the UK, more winter rainfall has been falling in intense events. A lake's water quality may therefore decline as a result of increased water temperatures and changes in the flow regime [36]. For the optimal management of lakes, detailed and accurate information of the effects of LREs/ EREs on lake water quality is necessary.

\section{Conclusions}

Based on our analysis of monthly monitoring data at the stations close to inflowing rivers in shallow eutrophic lakes, we observed that EREs ( $\geq 140 \mathrm{~mm}$ rainfall amount for 10 days in this study) resulted in flushing of phytoplankton communities and that some of the data taken after EREs well reflected the average values of inflowing water quality during EREs which could be measured with challenging work in field and laboratory. Because such water occupied a large part of the lake volume and because the water quality during EREs differed substantially from that in a baseflow condition, the effects of EREs on the lake water quality were significant; i.e., low in $\mathrm{COD}, \mathrm{Na}^{+}, \mathrm{Cl}^{-}$, Chla and high in $\mathrm{PO}_{4}{ }^{3-}-\mathrm{P}$, etc. In addition, the timing and magnitude of such events determined the behavior of the lake water quality. Algal production and/ or mixing with the downstream water would immediately change the water quality in Jun-Sep. In the events after LREs ( $50 \mathrm{~mm}$ to $140 \mathrm{~mm}$ rainfall amount for 10 days), fast recoveries of algal production usually occurred even in Oct to May. To distinguish the water quality after in-lake change, the percentiles of $\mathrm{Na}^{+}, \mathrm{Cl}^{-}$, and Chla were useful although more scientific determination of the threshold percentile value is expected in future. An increase in EREs due to climate change is possible, and evaluations of such events on the water quality of lakes are crucial for the lakes' sustainable management.

Acknowledgements This work was supported in part by Grants-in-Aid for Scientific Research from the Ministry of Education, Culture, Sport, Science and Technology (MEXT), Japan (17H04475 and 17H01850). Monitoring data on water quality were provided by Ibaraki Kasumigaura Environmental Science Center and National Institute for Environmental Studies (NIES). We thank two anonymous reviewers for their valuable comments and suggestions for improving the quality of the manuscript.

\section{Declarations}

Conflict of interest The authors declare that they have no conflict of interest.

Consent of publication All authors consented to submission of the manuscript for peer review.

Open Access This article is licensed under a Creative Commons Attribution 4.0 International License, which permits use, sharing, adaptation, distribution and reproduction in any medium or format, as long as you give appropriate credit to the original author(s) and the source, provide a link to the Creative Commons licence, and indicate if changes were made. The images or other third party material in this article are included in the article's Creative Commons licence, unless indicated otherwise in a credit line to the material. If material is not included in the article's Creative Commons licence and your intended use is not permitted by statutory regulation or exceeds the permitted use, you will need to obtain permission directly from the copyright holder. To view a copy of this licence, visit http://creativecommons. org/licenses/by/4.0/.

\section{References}

1. Kundzewicz ZW, Kanae S, Seneviratne SI, Handmer J, Nicholls N, Peduzzi P et al (2014) Flood risk and climate change: global and regional perspectives. Hydrol Sci J 59(1):1-28. https://doi.org/ 10.1080/02626667.2013.857411

2. O'Gorman PA (2015) Precipitation extremes under climate change. Curr Clim Change Rep 1(2):49-59. https://doi.org/10. 1007/s40641-015-0009-3 
3. Bao JW, Sherwood SC, Alexander LV, Evans JP (2017) Future increases in extreme precipitation exceed observed scaling rates. Nat Clim Change 7(2):128. https://doi.org/10.1038/nclim ate3201

4. Lehmann J, Coumou D, Frieler K (2015) Increased record-breaking precipitation events under global warming. Clim Change 132(4):501-515. https://doi.org/10.1007/s10584-015-1434-y

5. Brezonik PL, Stadelmann TH (2002) Analysis and predictive models of stormwater runoff volumes, loads, and pollutant concentrations from watersheds in the Twin Cities metropolitan area, Minnesota, USA. Water Res 36(7):1743-1757. https://doi.org/10. 1016/s0043-1354(01)00375-X

6. Gao Y, Zhu B, Yu GR, Chen WL, He NP, Wang T, Miao CY (2014) Coupled effects of biogeochemical and hydrological processes on $\mathrm{C}, \mathrm{N}$, and $\mathrm{P}$ export during extreme rainfall events in a purple soil watershed in southwestern China. J Hydrol 511:692-702. https://doi.org/10.1016/j.jhydrol.2014.02.005

7. Janke BD, Finlay JC, Hobbie SE, Baker LA, Sterner RW, Nidzgorski D, Wilson BN (2014) Contrasting influences of stormflow and baseflow pathways on nitrogen and phosphorus export from an urban watershed. Biogeochemistry 121(1):209-228. https:// doi.org/10.1007/s10533-013-9926-1

8. Zhu MY, Paerl HW, Zhu GW, Wu TF, Li W, Shi K et al (2014) The role of tropical cyclones in stimulating cyanobacterial (Microcystis spp.) blooms in hypertrophic Lake Taihu, China. Harmful Algae 39:310-321. https://doi.org/10.1016/j.hal.2014.09.003

9. Stockwell JD, Doubek JP, Adrian R, Anneville O, Carey CC, Carvalho $L$ et al (2020) Storm impacts on phytoplankton community dynamics in lakes. Glob Change Biol 26(5):2756-2784. https://doi.org/10.1111/gcb.15033

10. James RT, Chimney MJ, Sharfstein B, Engstrom DR, Schottler SP, East T, Jin KR (2008) Hurricane effects on a shallow lake ecosystem, Lake Okeechobee, Florida (USA). Fund Appl Limnol 172(4):273287. https://doi.org/10.1127/1863-9135/2008/0172-0273

11. Dolph CL, Boardman E, Danesh-Yazdi M, Finlay JC, Hansen AT, Baker AC, Dalzell B (2019) Phosphorus transport in intensively managed watersheds. Wat Resour Res 55(11):9148-9172. https://doi.org/10.1029/2018wr024009

12. Morabito G, Rogora M, Austoni M, Ciampittiello M (2018) Could the extreme meteorological events in Lake Maggiore watershed determine a climate-driven eutrophication process? Hydrobiologia 824(1):163-175. https://doi.org/10.1007/s10750-018-3549-4

13. Srifa A, Phlips EJ, Cichra MF, Hendrickson JC (2016) Phytoplankton dynamics in a subtropical lake dominated by cyanobacteria: cyanobacteria "Like it Hot" and sometimes dry. Aqua Ecol 50(2):163-174. https://doi.org/10.1007/ s10452-016-9565-4

14. Richardson J, Feuchtmayr H, Miller C, Hunter PD, Maberly SC, Carvalho L (2019) Response of cyanobacteria and phytoplankton abundance to warming, extreme rainfall events and nutrient enrichment. Global Change Biol 25(10):3365-3380. https://doi. org/10.1111/gcb.14701

15. de Eyto E, Jennings E, Ryder E, Sparber K, Dillane M, Dalton C, Poole $R$ (2016) Response of a humic lake ecosystem to an extreme precipitation event: physical, chemical, and biological implications. Inland Waters 6(4):483-498. https://doi.org/10.5268/iw-6.4.875

16. Asmala E, Osburn CL, Paerl RW, Paerl HW (2021) Elevated organic carbon pulses persist in estuarine environment after major storm events. Limnol Oceanogr Lett 6(1):43-50. https://doi.org/10.1002/ lol2.10169

17. Zhang Z, Fukushima T, Onda Y, Gomi T, Fukuyama T, Sidle R et al (2007) Nutrient runoff from forested watersheds in central Japan during typhoon storms: implications for understanding runoff mechanisms during storm events. Hydrol Process 21(9):11671178. https://doi.org/10.1002/hyp.6677
18. Eder A, Strauss P, Quinto KT (2010) Comparative calculation of suspended sediment loads with respect to hysteresis effects (in the Petzenkirchen catchment, Austria). J Hydrol 389(1-2):168176. https://doi.org/10.1016/j.jhydrol.2010.05.043

19. Zhang $Z$, Fukushima T, Onda $Y$, Mizugaki $S$, Gomi T, Kosugi $K$ et al (2008) Characterisation of diffuse pollutions from forested watersheds in Japan during storm events - Its association with rainfall and watershed features. Sci Total Environ 390(1):215226. https://doi.org/10.1016/j.scitotenv.2007.09.045

20. Ebise $S$ (1984) Regression models for estimation of storm runoff loading. Res Rep Natl Inst Environ Stud Jpn 50:59-88 ((in Japanese with English abstract))

21. Fukushima T, Aizaki M, Ebise S (1991) Dynamics of particulate matter near the mouth of influx river in Takahamairi Bay of Lake Kasumigaura with special reference to nitrogen and phosphorus. Jpn J Limnol 52:13-26

22. WEPA (2020) Lake Kasumigaura. http://www.wepa-db.net/polic ies/cases/kasumigaura/01-1.htm/. Accessed 1 May 2020

23. Ishikawa T, Tanaka M (1993) Diurnal stratification and its effects on wind-induced currents and water qualities in Lake Kasumigaura. Japan J Hydraul Res 31(3):307-322. https://doi.org/10. 1080/00221689309498828

24. Fukushima T, Muraoka K (1981) Current and vertical mixing in a shallow lake. Verh Internat Verein Limnol 21:141-149

25. National Institute for Environmental Studies (NIES) (2020) Lake Kasumigaura Database, National Institute Environmental Studies, Japan. http://db.cger.nies.go.jp/gem/inter/GEMS/database/ kasumi/index.html. Accessed 1 March 2020

26. Japan Meteorological Agency (JMA) (2020) Past meteorological data. http://www.data.jma.go.jp/obd/stats/etrn/. Accessed 1 March 2020

27. Fukushima $T$, Komuro $S$, Kitamura $T$, Nagahama $Y$, Matsushita B (2020) Long-term changes in water mineral concentrations and their influence on sediment water content in a shallow lake. SN Appl Sci 2:1319. https://doi.org/10.1007/ s42452-020-3119-z

28. Abell JM, Hamilton DP, Rutherford JC (2013) Quantifying temporal and spatial variations in sediment, nitrogen and phosphorus transport in stream inflows to a large eutrophic lake. Environ Sci-Pro Imp 15(6):137-1152. https://doi.org/10.1039/ c3em00083d

29. Fukushima T, Kamiya K, Onda Y, Imai A, Matsushige K (2010) Longterm changes in lake sediments and their influences on lake water quality in Japanese shallow lakes. Fund Appl Limnol 177:177-188. https://doi.org/10.1127/1863-9135/2010/0177-0177

30. Harris GP, Baxter G (1996) Interannual variability in phytoplankton biomass and species composition in a subtropical reservoir. Freshwater Biol 35(3):545-560. https://doi.org/10.1111/j.13652427.1996.tb01768.x

31. Abell JM, Hamilton DP (2015) Biogeochemical processes and phytoplankton nutrient limitation in the inflow transition zone of a large eutrophic lake during a summer rain event. Ecohydrology 8(2):243-262. https://doi.org/10.1002/eco.1503

32. Zhang YL, Shi K, Zhou YQ, Liu XH, Qin BQ (2016) Monitoring the river plume induced by heavy rainfall events in large, shallow, Lake Taihu using MODIS 250 m imagery. Remote Sens Environ 173:109-121. https://doi.org/10.1016/j.rse.2015.11.020

33. Page BP, Kumar A, Mishra DR (2018) A novel cross-satellite based assessment of the spatio-temporal development of a cyanobacterial harmful algal bloom. Int J Appl Earth Obs 66:69-81. https://doi.org/10.1016/j.jag.2017.11.003

34. Du CG, Li YM, Wang Q, Liu G, Zheng ZB, Mu M, Li Y (2017) Tempo-spatial dynamics of water quality and its response to river flow in estuary of Taihu Lake based on $\mathrm{GOCl}$ imagery. Environ Sci Pollut R 24(36):28079-28101. https://doi.org/10.1007/ s11356-017-0305-7 
35. Havens K, Paerl H, Phlips E, Zhu MY, Beaver J, Srifa A (2016) Extreme weather events and climate variability provide a lens to how shallow lakes may respond to climate change. Water 8(6):229. https://doi.org/10.3390/w8060229

36. Watts G, Battarbee RW, Bloomfield JP, Crossman J, Daccache A, Durance I et al (2015) Climate change and water in the UK
- past changes and future prospects. Prog Phys Geog 39(1):6-28. https://doi.org/10.1177/0309133314542957

Publisher's Note Springer Nature remains neutral with regard to jurisdictional claims in published maps and institutional affiliations. 